\title{
Niewerbalne elementy komunikacji w sytuacjach oficjalnych. Analiza debaty z udziałem liderów politycznych
}

\section{Nonverbal elements of communication in official situations. Political leaders' debate analysis}

\author{
Agata Karaśkiewicz \\ INSTYTUT JĘZYKOZNAWSTWA, UNIWERSYTET IM. ADAMA MICKIEWICZA \\ AL. NIEPODLEGŁOŚCI 4, 61-874 POZNAŃ \\ agata.karaskiewicz@wp.pl
}

\begin{abstract}
The primary goal of this article is to examine politicians ` nonverbal behaviors observed in the official situations, such as televised debate. Good communication is the foundation of successful relationships, both personally and professionally. But we communicate with much more than words. In fact, when we interact with others, we continuously give and receive countless wordless signals. This article aims at showing various nonverbal signals displayed by dominant polish political figures - leader of The Civic Platform Donald Tusk and The Law and Justice Jarosław Kaczyński. To set this idea a televised debate, which took place on September 12, 2007 before the country`s upcoming general election, is analyzed in detail. The author also looks how the behavior style is determined by the official character of the communication. In this context nonverbal signals observed in official face-to-face conversation between two interlocutors are discussed and may be the first step to further research of general tendency in nonverbal behavior.
\end{abstract}




\section{Wstęp}

Porozumiewanie się jest sztuką. A sztuka porozumiewania się jest jedną z tych umiejętności, z którymi mamy do czynienia przez całe życie i która znacząco wpływa na jego jakość.

Przyjmuje się, iż podstawę porozumiewania się ludzi stanowi komunikacja werbalna, jednakże słowa nie wyczerpują $\mathrm{w}$ pełni treści. Uzupełnieniem komunikacji werbalnej jest komunikacja niewerbalna, która niesie ogromny ładunek informacji, bez której porozumienie się, nawet $\mathrm{w}$ sytuacjach prozaicznych, nie byłoby skuteczne, albo wręcz niemożliwe. To właśnie zagadnieniu komunikacji niewerbalnej poświęcony jest niniejszy artykuł.

Kluczowym zamysłem jest próba zaprezentowania stylu zachowań polityków $\mathrm{w}$ sytuacjach oficjalnych $\mathrm{z}$ naciskiem na zachowania niewerbalne. Styl zmieniać się będzie w zależności od charakteru komunikacji - inny w sytuacjach oficjalnych i nieoficjalnych. Przypuszczać można więc, że konwencja wypowiedzi w sposób znaczący wpływa na sposób i rodzaj wykorzystanych środków niewerbalnych, na przykład na częstotliwość użycia gestów, jak i ich rodzaj. W sytuacjach oficjalnych, do jakich niewątpliwie zalicza się audycję publicystyczną, gestykulacja będzie najprawdopodobniej bardziej stonowana i przemyślana. Najczęściej wykonywanymi gestami będą prawdopodobnie te, które jedynie akcentują wypowiadaną treść, nie wnosząc żadnego dodatkowego znaczenia. Przypuszczalnie, bardzo rzadko u polityków zaobserwować będzie można natomiast ilustratory - „gesty oferujące komentarz do wypowiadanych słów, wprowadzające dodatkowe znaczenie nie wyrażone werbalnie"1, tak charakterystyczne dla sytuacji nieoficjalnych. Ponadto zakładać można, że w sytuacjach oficjalnych dyskutanci będą przywiązywać większą wagę do moderowania głosem, panowania nad emocjami i kontrolowania treści niewerbalnych wysyłanych przez ciało w ogóle. Ową hipotezę weryfikować będą wyniki przeprowadzonych przez autorkę badań.

\section{Material badawczy}

Wydarzeniem komunikacyjnym, które posłużyło jako materiał badawczy jest silnie nacechowana perswazja - przedwyborcza debata $\mathrm{z}$ udziałem kandydatów starających się objąć urząd premiera: przewodniczącego Platformy Obywatelskiej (PO), Donalda Tuska oraz Prawa i Sprawiedliwości (PiS), Jarosława Kaczyńskiego, która miała miejsce 12 października 2007 roku.

Nagrania (dwie 20 minutowe części oraz trzecia w 7 kilkuminutowych fragmentach-dostępne $\mathrm{w}$ takim formacie na stronie www.tvn24.pl) zostały opisane w programie Elan. Program ten umożliwia transkrypcję dialogów multimodalnych.

\footnotetext{
1 A. Załazińska, Schematy myśli wyrażane w gestach. Gesty metaforyczne obrazujące abstrakcyjne relacje i zasoby podmiotu mówiącego, Kraków, s. 20.
} 
Agata Karaśkiewicz: Niewerbalne elementy komunikacji w sytuacjach oficjalnych. Analiza debaty z udziałem liderów politycznych.

Dzięki niemu możliwy jest czytelny opis współwystępujących ze sobą warstw dialogu: układ ręki, jej ułożenie w przestrzeni, mimikę twarzy, ukierunkowanie głowy, pauzy, gesty i wokalizacje. Elan opracowany został w Instytut Maxa Plancka. Aby opisać styl zachowania polityków autorka wyszczególniła różne wymiary zachowań niewerbalnych, tj. spojrzenie, uśmiech, gestykulację, postawę ciała, ruch głowy oraz pauzy.

Analizowana debata jest dynamiczna, a ze względu na treść podzielona została na trzy części: pierwsza dotyczyła zagadnień gospodarczych, druga spraw międzynarodowych, trzecia - polityki krajowej. Każda $\mathrm{z}$ nich poprowadzona została przez znanych dziennikarzy: - Joannę Wrześniewską-Zygier z TV Biznes, Monikę Olejnik z TVN24 i Radia ZET i Krzysztofa Skowrońskiego z Polskiego Radia.

Każdy z polityków mógł zaprosić do studia po 65 osób, które stanowily widownię. Losowanie podczas próby technicznej przed debatą zdecydowało, że pierwszy na pytania odpowiadał Jarosław Kaczyński. Sporą rolę w debacie odgrywa również zgromadzona w studiu publiczność, żywo reagująca na wypowiedzi liderów partii.

\section{Metodologia}

Analizie poddane zostały zachowania niewerbalne przewodniczacego PO Donalda Tuska oraz prezesa PiS Jarosława Kaczyńskiego, które realizowane były przez polityków $\mathrm{w}$ trakcie telewizyjnej audycji publicystycznej.

Godzinna debata z udziałem liderów Jarosława Kaczyńskiego i Donalda Tuska została opisana według wymiarów wyróżnionych przez autorkę pracy oraz poddana analizie. Celem opisu zjawisk komunikacyjnych na poziomie komunikacji niewerbalnej jest próba wyłonienia tendencji zauważalnych $\mathrm{w}$ sferze zachowań niewerbalnych realizowanych w sytuacjach oficjalnych.

Ze względu na specyfikę materiału (tj. sposób filmowania, ujęcia, ruchy kamery itp.) nie wszystkie zachowania niewerbalne mogły zostać opisane, dlatego prezentowane $\mathrm{w}$ analizie materiały nie obejmują wszystkich realizowanych przez polityków zachowań. (Zgromadzony materiał nie był bowiem nagrywany $\mathrm{w}$ tymże celu, nie wszystkie zachowania są więc widoczne).

Aby opisać styl zachowania polityków, wyróżniono kilka kategorii zachowań niewerbalnych, tj. spojrzenie, uśmiech, gestykulację, postawę ciała, ruch głowy oraz pauzy które opisane zostały w osobnych warstwach programu Elan. W ich obrębie wyróżnione zostały dodatkowe podkategorie.

\subsection{Spojrzenie:}

\section{Zachowanie JK/ DT podczas gdy dziennikarz zadaje mu pytanie}

1. JK/DT spogląda na dziennikarza cały czas 
2. JK/DT spogląda na dziennikarza przerwanie

3. JK/DT w ogóle nie spogląda na dziennikarza

\section{Zachowanie JK/DT podezas gdy rozmówca zadaje mu pytanie}

1. JK/DT spogląda na rozmówcę cały czas

2. JK/DT spogląda na rozmówcę przerwanie

3. JK/DT w ogóle nie spogląda na rozmówcę

\section{Zachowanie JK/DT podezas zadawania pytania rozmówcy}

1. JK/DT zadając pytanie spogląda na rozmówcę cały czas

2. JK/DT zadając pytanie spogląda na rozmówcę przerwanie

3. JK/DT zadając pytanie w ogóle nie spogląda na rozmówcę

\section{Zachowanie JK/DT podczas odpowiadania na pytanie dziennikarza}

1. JK/DT odpowiadając na pytanie dziennikarza spogląda na niego cały czas.

2. JK/DT odpowiadając na pytanie dziennikarza spogląda na niego przerwanie

3. JK/DT odpowiadając na pytanie dziennikarza w ogóle na niego nie spogląda

\section{Zachowanie JK/DT podezas gdy rozmówca odpowiada na pytanie dziennikarza}

1. Kiedy rozmówca odpowiada na pytanie dziennikarza, JK/DT spogląda na rozmówcę cały czas

2. Kiedy rozmówca odpowiada na pytanie dziennikarza, JK/DT spogląda na rozmówcę przerwanie

3. Kiedy rozmówca odpowiada na pytanie dziennikarza, JK/DT w ogóle nie spogląda na rozmówcę

\section{Zachowanie JK/DT podczas odpowiadania na pytanie rozmówcy}

1. JK/DT odpowiadając na pytanie rozmówcy spogląda na niego cały czas

2. JK/DT odpowiadając na pytanie rozmówcy spogląda na niego przerwanie

3. JK/DT odpowiadając na pytanie rozmówcy w ogóle na niego nie spogląda

\section{Zachowanie JK/DT podczas gdy rozmówca odpowiada na jego pytanie}

1. Kiedy rozmówca odpowiada na pytanie, JK/DT spogląda na niego cały czas 
Agata Karaśkiewicz: Niewerbalne elementy komunikacji w sytuacjach oficjalnych. Analiza debaty z udziałem liderów politycznych.

2. Kiedy rozmówca odpowiada na pytanie, JK/DT spogląda na niego przerwanie

3. Kiedy rozmówca odpowiada na pytanie, JK/DT w ogóle na niego nie spogląda

\subsection{Uśmiech:}

Uśmiech numer 1: bardzo delikatny, (krótki, symetryczny, bez wokalizacji, angażujący mięsień jarzmowy $\left.{ }_{177}\right)$,

Uśmiech numer 2: ironiczny (niesymetryczny, bez wokalizacji, angażujący mięsień jarzmowy 178 ),

Uśmiech numer 3: ironiczny śmiech (niesymetryczny, z wokalizacją179), Uśmiech numer 4: naturalny śmiech, szczery, pełną buzią (symetryczny, $\mathrm{z}$ wokalizacją180),

\subsection{Kanał wokalny (przerwy):}

Pauza numer 1: uczestnik na chwilę przerywa wypowiedź, gdy publiczność klaszcze

Pauza numer 2: uczestnik szuka słowa

Pauza numer 3: uczestnik przerywa, gdy w słowo wchodzi mu rozmówca, lub prowadząca

\subsection{Ruch głowy:}

Ruch numer 1: uczestnik skinieniem głowy potwierdza chęć zabrania głosu.

Ruch numer 2: uczestnik skinieniem głowy potwierdza swoje słowa.

\subsection{Postawa ciala:}

JK/DT słuchając wypowiedzi rozmówcy

1. zwrócony jest do niego ciałem

2. nie jest zwrócony do niego ciałem

\section{JK/DT zadając pytanie rozmówcy}

1. zwrócony jest do niego ciałem

2. nie jest zwrócony do niego ciałem

\section{JK/DT odpowiadając na pytanie rozmówcy}

1. zwrócony jest do niego ciałem

2. nie jest zwrócony do niego ciałem

\subsection{Gestykulacja:}

Gest 1 - ilustrujący wypowiadaną treść (ilustratory, gesty metaforyczne), Gest 2 - akcentujący wypowiadaną treść (gesty deiktyczne, uderzenia). 


\section{Wnioski}

Znaczną część życia spędzamy na komunikowaniu się. Każda sytuacja społeczna implikuje proces nadawania i odbierania różnych informacji. Rola języka i mowy dla gatunku homo sapiens jest fundamentalna „słowo jako symbol przenosi myśl w sfery realne i imaginacyjne, w przeszłość i przyszłość na równi z teraźniejszością”, jednakże ogromne znaczenie dla skuteczności porozumiewania się mają gestykulacja i wszelkie zachowania pozajęzykowe. Są to pierwsze, podstawowe sposoby obrazowania myśli, które nie tworzą oderwanego od mowy systemu, ale go wspomagają i wzbogacają w nowe treści semantycznes.

W rzeczy samej, ręce zawsze będą uczestniczyć w procesie komunikacji, gdyż „gama ludzkich doświadczeń i doznawanych emocji jest daleko szersza niż liczba słów i wyrażeń je nazywających, nawet w najbardziej wyrafinowanym formalnie języku, poza tym procesowanie mentalne jest szybsze niż nasza zdolność wypowiadania słów $4 "$.

Dotychczasowe doświadczenia w dziedzinie komunikacji wskazują, że mowa i ruchy ciała razem stanowią pełny komunikat. „Ruchy (symbole) nie są po prostu substytutami słów - treści przekazywane środkami parajęzykowymi nie powielają po prostu znaczeń, lecz je uzupełniają, wprowadzając dodatkowe wymiary kognitywnego procesowanie sensów5" . Komunikacja pozajęzykowa powinna być więc analizowana jako integralna część całościowo pojmowanego procesu porozumiewania się.

Dzisiaj komunikacja niewerbalna jest niezwykle ważnym aspektem komunikowania się z otoczeniem, zaczynamy zdawać sobie coraz większa sprawę z jej istnienia, a tym bardziej znaczenia. Nader wszystko chęć zrozumienia komunikacji i skutecznego ocenienia jej przebiegu jest naturalną potrzebą każdego człowieka, a zrozumienie i efektywne wykorzystanie zachowań niewerbalnych niewątpliwie może przynieść korzyści niemal we wszystkich dziedzinach życia.

Od kilku lat można zauważyć wzrost zainteresowania wpływem sygnałów niewerbalnych na powodzenie politycznych kampanii wyborczych i debat telewizyjnych. Wiąże się to $\mathrm{z}$ zajmującym coraz ważniejsze miejsce w życiu politycznym - wizerunkiem i jego kreowaniem. W krajach zachodnich owe procesy są zaawansowane, jednak w Polsce to wciąż temat stosunkowo świeży, ale wzbudzający coraz większe zainteresowanie.

W przeprowadzonej analizie zauważa się pewne problemy we współczesnym modelu dyskutowania na forum publicznym: ważną rolę odgrywa zgromadzona $\mathrm{w}$ studiu publiczność, żywo reagująca na wypowiedzi liderów partii. Zwolennicy Tuska kilkakrotnie wykrzykują

2 T. Goban-Klas, 2006. Media $i$ komunikowanie masowe. Warszawa: Wydawnictwo Naukowe PWN.

3 Antas 2001: 439.

4 Antas 2001: 439.

5 Antas 1996. 


\section{Agata Karaśkiewicz: Niewerbalne elementy komunikacji w sytuacjach oficjalnych. Analiza debaty z udziałem liderów politycznych.}

nieprzyjemne pytania i epitety pod adresem J. Kaczyńskiego. Widownia (znajdująca się z tyłu, za kandydatami) często reaguje śmiechem, klaszcze. Jarosławowi Kaczyńskiemu publiczność w nieelegancki sposób przerywała wypowiedzi aż 46 razy. Dla porównania Donaldowi Tuskowi tylko 9, w dodatku w większości przypadków lagodniej. Zaobserwować można również prowokacyjne zachowanie dziennikarzy, ich stronniczość: żaden z prowadzących nie podjął nawet jednej próby zdyscyplinowania publiczności. Tolerancja dziennikarzy, w stosunku do faktów łamania ustalonych wcześniej reguł debaty, przez lidera PO była także większa, niż miało to miejsce w przypadku przewodniczącego PiS. Donaldowi Tuskowi pozwolono mówić po sygnale dźwiękowym, oznaczającym koniec czasu na wypowiedź aż 8 razy; Jarosławowi Kaczyńskiemu o połowę mniej. W wypowiedzi Jarosława Kaczyńskiego dziennikarze ingerowali 9 razy; w Donalda Tuska 7. W jednym przypadku Monika Olejnik pozwoliła sobie wobec lidera PiS-u na niedopuszczalny komentarz - sugerując, iż do debaty przygotowała go propagandowo ręka Neli Rokity.

Zarówno zachowanie publiczności, jak i stronniczość prowadzących niewątpliwie dawały Tuskowi pewnego rodzaju przewagę, jednocześnie przeszkadzając premierowi. Zgromadzone $\mathrm{w}$ telewizyjnym studiu audytorium swoim zachowaniem mogło narzucać ocenę wyborcom, który z polityków ma rację, lepiej argumentuje, przekonuje i na którego należy zagłosować podczas wyborów, choć niekoniecznie musiało to mieć związek $\mathrm{z}$ wygłaszanymi przez nich treściami.

Badanie zjawisk komunikacyjnych (na poziomie komunikacji niewerbalnej) umożliwiło wyłonienie pewnych tendencji zauważalnych $\mathrm{w}$ sferze zachowań niewerbalnych realizowanych przez polityków $\mathrm{w}$ sytuacjach oficjalnych. Zauważyć można wiele podobieństw w zachowaniu liderów politycznych biorących udział w debacie.

Zarówno w wypowiedziach Donalda Tuska, jak i Jarosława Kaczyńskiego, jeśli występowały elementy humorystyczne, to zwykle (w 43,4\% przypadków) towarzyszył im naturalny, szczery śmiech pełną buzią (rodzaj uśmiechu numer 4 - pojawił się 8 razy u Jarosława Kaczyńskiego i 9 razy u Donalda Tuska). Na drugim miejscu z prawie 31\% plasuje się uśmiech bardzo delikatny, krótki, symetryczny, bez wokalizacji, (rodzaj uśmiechu numer 1). Przeważnie występuje, gdy liderzy mówią o miłości do ojczyzny, o pozytywnym świecie, który chcą budować, o wierze w Polaków itp. Trzecie miejsce przypada na szyderczy uśmiech (rodzaj uśmiechu numer 2) u Donalda Tuska obserwowany 7 razy - w 18\% wszystkich uśmiechów. Jest wyrazem dezaprobaty i szydzenia ze stanowiska zajmowanego przez ideologicznego oponenta, wypominania mu błędów z przeszłości, pouczania. Ostatni rodzaj uśmiechu, zabarwiony sarkazmem i ironią (rodzaj uśmiechu numer 3- dwukrotnie obserwowany u Donalda Tuska oraz jednokrotnie u Jarosława Kaczyńskiego), stanowi 8\% wszystkich analizowanych przypadków. Pojawia się, gdy dyskutanci podważają wiarygodność swych sądów, zrzucają winę i odpowiedzialność na przeciwnika. 
Znamienne, iż obaj politycy przyjmują również podobną pozycję ciała w trakcie rozmowy. Dla obu kandydatów charakterystyczne jest zwracanie się całym tułowiem do swojego rozmówcy, pochylanie ku niemu, zarówno w trakcie zadawania mu pytań, słuchania jego wypowiedzi czy pytań a także udzielania mu odpowiedzi. W trakcie debaty nie zdarzyło się, aby któryś z nich nie przyjmował takiej pozycji ciała.

Podobna jest również gestykulacja Jarosława Kaczyńskiego i Donalda Tuska. W przeciwieństwie na przykład do uczestników programów rozrywkowych typu talk-show, zdecydowana większość wszystkich gestów wykonywanych przez obu polityków to gesty podkreślające wypowiadaną treść, ale nie wnoszące do niej żadnych dodatkowych informacji. Rzadko pojawiały się więc ilustratory, czyli gesty wspierające treściowo wypowiedź, zwiększające jasność ekspresji i klarowność przekazu- tak charakterystyczne dla showmanów. Zauważa się, że gesty polityków przeważnie są stonowane, nieagresywne, otwarte. Obserwacja materiału pozwala dokładnie wyliczyć ilość wszystkich występujących w 60 minutowej debacie gestów: 95\% (1546 gestów, z czego 752 wykonuje Tusk, a pozostałe 794 Jarosław Kaczyński) stanowią gesty (rodzaj gestykulacji numer 2) akcentujące wypowiadane treści. Do nich należą gesty deiktyczne oraz uderzenia. Pozostałe $5 \%$ to gesty obrazujące konkretne przedmioty, własności lub zdarzenia, najczęściej zapowiadające treść do której się odnoszą (rodzaj gestu numer 1). W ich obrębie pojawiały się gesty ikoniczne oraz metaforyczne). Ilustratory wystąpiły w sumie 82 razy, w tym 59 razy w wykonaniu przewodniczaccego Platformy i tylko 23 razy w wykonaniu premiera Jarosława Kaczyńskiego. Obaj kandydaci na fotel premiera szczególnie żywo gestykulowali zwłaszcza wtedy, gdy byli bardzo przejęci, podekscytowani.

Głos obu kandydatów był raczej pewny, miły, bez rażących wad wymowy. Mówili wyraźnie z odpowiednią dykcją. Z wyróżnionych w kluczu kategoryzacyjnym trzech rodzajów pauz ponad połowa $(54,2 \%)$ odnosi się do przerwy (rodzaj pauzy numer 1) wynikającej ze specyfiki telewizyjnej audycji publicystycznej (w przypadku Kaczyńskiego miała ona miejsce 8 razy, w przypadku Tuska 5). Kiedy audytorium klaszcze, rozmówca zmuszony jest do przerwania wypowiedzi, mimo wysiłków nie jest bowiem w stanie przekrzyczeć aplauzu publiczności. Wynika to z faktu, iż debata docelowo nie była nagrywana pod kątem analizy komunikacji niewerbalnej. W prawie 30\% obserwować można krótką pauzę konieczną do znalezienia odpowiedniego środka werbalnego (rodzaj pauzy numer 2-4 razy pojawiła się podczas wypowiedziach Jarosława Kaczyńskiego, 3 razy w wypowiedziach Donalda Tuska). Ma ona miejsce szczególnie w przypadku, gdy rozmówca jest rozkojarzony, zbity z tropu, albo wręcz wyprowadzony z równowagi (na przykład, gdy widownia śmieje się, głośno komentuje, wręcz prowokuje). Niecałe $17 \%$ (rodzaj pauzy numer 3 przypadająca po 2 razy dla obu dyskutantów) to sytuacja, w której polityk zmuszony jest do przerwania wypowiedzi, ponieważ w słowo wchodzi mu rozmówca lub prowadzący/a. 
Agata Karaśkiewicz: Niewerbalne elementy komunikacji w sytuacjach oficjalnych. Analiza debaty z udziałem liderów politycznych.

Jedyną różnicę $\mathrm{w}$ zachowaniach komunikacyjnych $\mathrm{w}$ sferze komunikacji pozajęzykowej obu liderów obserwujemy w przypadku zachowań wzrokowych. Donald Tusk niemal bezustannie utrzymywał kontakt wzrokowy zarówno z dziennikarzem, jak i swoim rozmówcą, bez względu na sytuację komunikacyjną. Innymi słowy, zadając pytanie, udzielając odpowiedzi Jarosławowi Kaczyńskiemu, słuchając wypowiedzi dyskutanta itp. ani na chwilę nie spuszczał wzroku z osoby z którą się $\mathrm{w}$ danej chwili komunikował. Jedynie odpowiadając na pytanie prowadzącego spoglądał na niego z przerwami. Inaczej było jednak $\mathrm{w}$ przypadku prezesa PiS, który we wszystkich analizowanych przypadkach patrzył na swojego rozmówcę z przerwami, tj. nie patrzył cały czas, spoglądał bowiem także w notatki, przed siebie, w kamerę itd. Być może wynika to z faktu, iż szef PO był przeszkolony w kwestii utrzymywania kontaktu wzrokowego, choć nie ma co do tego pewności.

Obaj rozmówcy od początku debaty nastawieni są wojowniczo i nie kryją negatywnej postawy wobec swojego przeciwnika politycznego i jego poglądów. Są stanowczy i zdeterminowani.

$\mathrm{Na}$ początku debaty zarządzają turami konwersacyjnymi, jednak z biegiem czasu przestają przestrzegać reguł ustalonych przez swoje sztaby wyborcze - wchodzą sobie w słowo, przekrzykują nawzajem, głośno domagają się odpowiedzi na konkretne pytania, ignorują nawet prowadzących.

Przez większość czasu trwania dyskusji politykom udaje się panować nad swoimi emocjami, nie łatwo dają wyprowadzić się z równowagi czy zbić z tropu. Obaj często jednak formułują dosadne, złośliwe riposty, śmieją z siebie nawzajem i otwarcie krytykują zajmowane stanowiska. Niejednokrotnie są uszczypliwi, ale wykazują się też poczuciem humoru.

Analiza materiału pozwala również postawić hipotezę, że jedną $\mathrm{z}$ najważniejszych form pozyskiwania audytorium telewizyjnego są śmiałe, choć skrywane pod powierzchnią tekstu, strategie służące autokreacji, a komunikacja niewerbalna jest do tego narzędziem.

Wnioski $\mathrm{z}$ przeprowadzonej analizy podkreślaja raz jeszcze elementarną rolę komunikacji niewerbalnej w ogólnym procesie porozumiewania się, także $\mathrm{w}$ sytuacjach oficjalnych, takich jak przedwyborcza debata. Mogą stanowić również pierwszy krok do wskazania ogólnych tendencji w zachowaniach polityków z naciskiem na sferę niewerbalną. 


\section{Bibliografia}

Antas, Jolanta 1996. Gest, mowa a myśl, Lublin.

Antas, Jolanta 2001. Co mówia ręce, wprowadzenie do komunikacji niewerbalnej. In: „Retoryka dziś. Teoria i praktyka. Ed. R. Przybylska and W. Przyczyna, Kraków, pp. 437-459

Antas, Jolanta 2006. Gestures: images of concepts and schemata of thoughts. In: "Iconicty in Language and Literature". Ed. E. Tabakowska, Kraków: Universitas.

Chawla, P., \& Krauss, R. M. 1994. Gesture and speech in spontaneous and rehearsed narratives. Journal of Experimental Social Psychology, 30, 580601.

De Ruiter, J-P. 2000. The production of gesture and speech. In D. McNeill (Ed.), Language and Gesture ( $p p$. 284-311). Cambridge: Cambridge University Press.

Ekman, P., \& Friesen, W. V. 1972. Hand movements. Journal of Communication, 22, 353-374.

Emmorey, K. 1999. Do signers gesture? In. L. Messing\&R. Campbell (Eds.), Gesture, speech, and sign (pp. 133-159). New-York: Oxford University Press.

Feyeriesen, P., Van de Wiele, M., \& Dubois, F. 1988. The meaning of gestures: What can be understood without speech? Cahiers de Psychologie Cognitive, 8, 3-25.

Goldin - Meadow, S. 2003. Hearing Gesture: How Our Hands Help UsThink. Cambridge: Harvard University Press.

Kendon, Adam 1994. Do gestures communicate?: A review. Research on Language and Social Interaction., 27, 175-200.

Kendon, Adam 1988. How gestures can become like words. In F. Poyatos (Ed.), Crosscultural perspectives in nonverbal communication, pp. 131-141. Toronto: Hogrefe.

McNeill, David 2000 Introduction. In D. McNeill (ed.), Language and gesture, pp. 1-10. Cambridge: Cambridge University Press.

McNeill, David 2005. Gesture and thought. Chicago: University of Chicago Press.

McNeill, David 2006. Gesture, gaze, and ground. In S. Renals \& S.S. Benglo (Eds.), MLMI 2005. LNCS 3869, pp. 1-14.

Mc Neill, David 1992. What gestures reveal about thought. Chicago and London: The Univ. of Chicago Press.

Corballis, Michael C. 2002. From hand to mouth: The origins of language. Princeton, NJ: Princeton University Press.

Załazińska A. (2001): Schematy myśli wyrażane w gestach. Gesty metaforyczne obrazujące abstrakcyjne relacje $i$ zasoby podmiotu mówionego, Kraków: Universitas. 